\title{
MISS LILIAN M. DEIGNAN \\ THE FIRST B. COMM. GRADUATE FROM UNIVERSITY COLLEGE DUBLIN
}

\author{
Peter Clarke \\ University College Dublin
}

\begin{abstract}
$\mathrm{T}$

he late Mrs Lilian Mary Buckley (née Deignan) has the distinction of being the first individual to graduate with a B. Comm. degree from University College Dublin. This unique distinction was achieved in October 1914 but has not, until now, been widely acknowledged or reported. This paper attempts to partly rectify this omission and outlines aspects of her life (1893-1970), which can be divided into her pre-university, university and post-university experience; these three phases are discussed in the context of a changing economic and social Ireland in the early twentieth century.
\end{abstract}

\section{INTRODUCTION}

The inspiration and motivation for this paper was provided a little while ago when this author was researching aspects of the life of the late Charles Hubert Oldham, the first Professor of Commerce in the newly created University College Dublin (UCD) and the first dean of the Faculty of Commerce at that university (Clarke, Ó hÓgartaigh and Ó hÓgartaigh, 2010). The author uncovered the possibility that Lilian Mary Deignan was the first individual to graduate with a B. Comm. degree from University College Dublin and that this was achieved at the graduation ceremony of October 1914 (Report of the President, 1913-14, p. 50).The graduation and significant achievement of Lilian Deignan at that time - 100 years ago - stimulated personal curiosity for a number of reasons. Firstly, the author (and his immediate colleagues) was surprised that the first B. Comm. graduate from University College Dublin was female, when in fact females represented only about 10 per cent of the total student population of University College Dublin during the two years 
before Lilian Deignan entered the university in October 1911 (Report of the President, 1935-1936, p. 24). A similar situation existed in University College Cork, for example, where there was only a small number of women students (Murphy, 1995). Indeed, in the volumes of copious discussion by the Dublin Commission (1909) in relation to commerce/business education, the terms 'men' and 'business men' were universally used, with no reference to females. Secondly, and in the context that Miss Lilian Deignan was a scholarship student, Commerce degrees around that time lacked overall status in the community, with one early and distinguished Commerce graduate of UCD suggesting, in a slightly over-critical manner, that 'the Commerce degree at that time had the lowest standing in Academe, below even the pass degree in Trinity College which had an exceptionally poor reputation' (Andrews, 1982, p. 39). A subsequent report on the Faculty of Commerce argued that the programme of the Faculty of Commerce had not been developed or equipped so as to adequately discharge its educational purpose (National University of Ireland, 1919). Thirdly, the Faculty of Commerce had previously publicised (in 2008) that they were celebrating 100 years of education. However, the selected year (2008) related to the legislation enabling the creation of University College Dublin through the Irish Universities Act 1908. It was in the following year (1909) that the first appointments in 'Commerce' subjects to the newly created Faculty of Commerce at University College Dublin were made; the faculty held its first meeting in March 1910; the first B. Comm. students began their studies in the autumn of 1911; the first Commerce examinations were held in 1912; and the first graduates of the faculty were conferred in 1914 (Clarke et al., 2010). Thus, it would also have been appropriate to celebrate 100 years of actual Commerce education in any of the years between 1909 and 1914 (inclusive), with the latter date representing the date of graduation of Lilian Mary Deignan - the first graduate of the B. Comm. programme.

This paper reports biographical research on various aspects of the life of the first B. Comm. graduate of University College Dublin, Lilian Deignan (1893-1970), in the context of the emerging business education sector in Ireland, together with a changing economic and social Ireland around the beginning of the twentieth century. While some research on prominent individuals in accounting/business education in Ireland has been published in recent years (for example, Keogh and Keogh, 2010; Clarke et al., 2010; Clarke, 2005) the area of biographical research is a relatively neglected one. This is a curious omission since accounting/business history is not limited to a sterile description of techniques and developments. Rather, accounting/business history should also concern itself with those individuals who shaped and were shaped by those developments, or were instrumental in their prevention. Thus, accounting/business history is a fundamental part of social history, and biographical research allows us to better understand social history. Following on from this, Flesher and Flesher (2003) argue, biographical research involves the discovery of facts about an individual's life but a collection of facts does not make a biography. Rather, there must be a narrative and a context.

This paper is structured as follows. In the next section I describe the pre-university years of Lilian Deignan. This is followed by a section on the newly created Faculty of Commerce at University College Dublin within which Lilian studied for her B. 
Comm. degree. The post-university life of Lilian Deignan is then described. A short concluding section ends this paper.

\section{THE EARLY YEARS}

The first public record found relating to Lilian Deignan was that contained in the 1901 Census of Ireland, where she is listed as Lily M. Deignan, residing in a house in Shinrone, King's County (now County Offaly), and entered as a Roman Catholic, then aged seven years, born in Fermanagh and whose occupation was listed as a scholar, i.e. a school pupil (National Archives of Ireland, 1901). She was listed as one of five children: John (nine years), Lily (seven years), Thomas (five years), Michael (four years) and Edward (two years); and the three eldest were listed as being able to 'read and write'. Her mother, Margareta, then aged 34, was born in Fermanagh, as was Lilian, but her siblings were all born in Cavan. These curious birth location entries were clarified by examining the subsequent 1911 Census, which lists the Deignan family as residing in Duke Street, Birr, and reports that Patrick Deignan (the father, 57 years) was a head constable of the Royal Irish Constabulary (RIC) and indicates that he was born in Sligo (National Archives of Ireland, 1911). That census return also reveals three additional children to the family: Francis (nine years), Margaret (seven years) and Sarah (four years), all of whom were born in King's County, making a total of eight children in the Deignan family, of whom Lilian was the second eldest.

A listing of members of the Royal Irish Constabulary (Winters, 1893) confirms that Sergeant P. Deignan was stationed at Ballinagh, County Cavan during the 1891 Census. ${ }^{1}$ The police force at that time, according to one contemporary recruit, offered many attractions, with a salary equal to that of a bank clerk, civil servant or schoolteacher, but with the prospects of advancement being much better and with a lodging allowance being provided for married men. Moreover, while a schoolteacher and bank clerk would be confined within the narrow space of a classroom or behind a bank counter, the RIC constable would be out in the open air (Gaughan, 1975). The successful royal visit by Queen Victoria in 1900 emphasised the notion that policing in Ireland was 'enjoying a period of civil tranquillity' (McCarthy, 2012, p. 33). Lee (1990) notes that the change in the attitude of the people towards British rule in Ireland between Easter 1916 - following the executions of the rebel leaders of the failed Rising - and June 1918 was astonishing, and that the RIC, which was an 80 per cent Irish Catholic force, had to endure the release of public wrath as an unexpected swing of support towards republicanism unfolded. In subsequent times, Patrick Deignan was reported as acting as manager of the Birr Electric Light and Power Company for 'many years and was a highly efficient business executive. He was a kind and popular gentleman' and died, aged 88 years, in 1948 (Nenagh Guardian, 29 May 1948, p. 8). He was predeceased by his wife, Margaret, who died in 1944 (Irish Independent, 11 January 1944, p. 1).

By the time of the 1911 Census, Lilian Deignan was listed as resident in house 3 in Monaghan town (National Archives of Ireland, 1911). In fact, she was a pupil at the prestigious and highly regarded St Louis Convent in Monaghan town, and was 
then aged seventeen years. On that Census return form, her birthplace was incorrectly listed as 'Birr, King's County', but this error is understandable considering that there were over 120 (boarding) pupils listed that evening in the school (in addition to five teachers), with ages ranging from six to eighteen years. It is interesting to note that this 1911 Census return indicated that 28 different (Irish) counties of birth were represented by pupils of the school that evening. Assuming that these counties of birth were equivalent to the county of residence for each pupil, this highlights the geographical spread of the pupils of that convent and represents a remarkable representation given the logistical efforts encountered by some pupils who had to travel long distances at that time. ${ }^{2}$

While attending St Louis Convent in Monaghan town, Lilian Deignan was awarded a prestigious Bronze Medal and a $£ 3$ prize at Middle Grade of the Intermediate Examination, having obtained the highest marks (for girls in Ireland) in the Honours examination in Italian; her interest in the Italian language would be maintained in her subsequent studies in University College Dublin and thereafter. Many pupils of St Louis Convent, Monaghan received various awards and prizes in various examinations at senior, middle and junior grade examinations (Irish Times, 17 September 1910). These collective examination performances highlight the excellent reputation and high standard of education provided to the pupils of that convent. However, such achievements were attained through motivation and hard work. For example, Sister Laurentia, a former pupil and subsequent nun at St Louis for some years, stated in her (unpublished) memoirs that when she became a boarder at St Louis Convent, Monaghan (in 1897) the pupils were urged to challenge Protestant supremacy in the exhibition lists and she remembered that the senior and middle grade students got up voluntarily around 5 a.m. for months before the examination (Ó hÓgartaigh, 2011).

However, access to university education for Catholics in Ireland at that time was problematic. Coolahan (1981) explains that the only (full) university in Ireland was Trinity College - the University of Dublin - which had a Church of Ireland ethos. The university had abolished all religious tests for admitting students in 1873 only for the Catholic hierarchy to oppose Catholic attendance at that university in 1875 . In addition, it was clear that the non-denominational Queen's Colleges, established at Belfast, Cork and Galway during the 1840s, and condemned by the Catholic hierarchy at the Synod of Thurles in 1850, were not a satisfactory solution to the needs of Irish university education. Moreover, the Catholic University, formally opened in 1854, was languishing in the absence of sufficient endowment, poor public support, some ecclesiastical opposition and declining student numbers. Thus, after a long and difficult process an acceptable solution was arrived at, and this was contained in the Irish Universities Act 1908, which left the status and operation of the University of Dublin (i.e. Trinity College) unchanged (Maxwell, 1946). The Act established two new universities in Ireland. The old Queen's College in Belfast was raised to the status of a full university with non-denominational status. In addition, a federal National University of Ireland was established which would embrace the existing Queen's Colleges at Cork and Galway and the newly formed University College Dublin. Though legally non-denominational, the background of the students and the religion of the majority of the governing bodies and staff ensured that these 
three university colleges would reflect a Catholic ethos, and they were accepted and supported by the Catholic hierarchy (Coolahan, 1981). However, Bartlett comments (2010, p. 366) that:

No one appears to have noticed that setting up two universities [Queen's University Belfast and the National University of Ireland], each organised on a different basis, directed at different religious communities, and located in different parts of the country, might presage some form of partition.

University College Dublin began life as a teaching institution on 2 November 1909 when it enrolled just over 500 students, of whom 90 per cent were male (McCartney, 1999). The statutes of the Irish Universities Act 1908 (Chapters XI and XVI) provided for the establishment of a Faculty of Commerce at UCD. ${ }^{3}$ The Dublin Commission - the statutory body that was entrusted to make all appointments to the National University of Ireland - appointed Charles Hubert Oldham as the (first) Professor of Commerce at UCD on Saturday 23 October $1909^{4}$ and the first meeting of the UCD Faculty of Commerce was held on 31 March 1910, during which it was agreed that Oldham be chosen as dean of the Faculty of Commerce in UCD (Faculty of Commerce, 1910). As far as can be ascertained, Professor Oldham delivered the first lectures in the Faculty of Commerce, dealing with international commerce, commencing in January 1910 on Tuesday and Thursday afternoons at 4.30 p.m. in Earlsfort Terrace in the Hilary (i.e. January to March) and Trinity (i.e. April to May) terms. Subsequently it was reported that Commerce lectures 'were attended by students of the BA and MA classes in economics as well as by other voluntary students' (Report of the President, 1910-11, p. 10). The first B. Comm. students commenced their studies in the autumn of 1911 but lectures in commerce at that time were largely attended by non-university students (Report of the President, 1911-12).

In addition to its academic remit, the Irish Universities Act 1908 (section 10.2) empowered any local rating authority to award scholarships tenable in any university in Ireland. The regulations attaching to the scholarship schemes varied from county to county and from time to time, but Irish was insisted upon in all cases (Return of Scholarships, 1913). McCartney (1999) adds that it was clear from the involvement of county councillors on the governing bodies of the universities and from the debates in Parliament in 1908 that these scholarships were intended to provide an additional source of income for the (underfunded) colleges. Special examinations for scholarship applicants were set by the college, and the scholarship holders undoubtedly raised academic standards. In addition, the Freeman's Journal expressed the opinion that 'these valuable prizes are a splendid stimulus and reward to ambitious students eager to proceed from a successful secondary school course to the culture of a university career' (23 October 1912, p. 5).

The 1908 Act, while conferring on women equality with men in all matters relating to university education, also ensured that women had to attend university to obtain degrees; prior to the 1908 Act, women could obtain degrees from the Royal University, which organised examinations, by attending, for example, Loreto, Dominican, Sacred Heart and other 'recognised' convents/colleges. Thus, 
the refusal to continue 'recognised' status for these female colleges ensured that women students had to come instead to one of the National University of Ireland colleges (McCartney, 1999). Thus, Lilian Deignan is listed as one of the five King's County scholarship holders - which were worth $£ 50$ a year, tenable for three years, subject to satisfactory grades - with her father being listed as a head constable (Return of Scholarships, 1913). The Academic Council of University College Dublin had noted that she qualified for a King's County scholarship, averaging 45 per cent in her entrance exam (Academic Council, 1911). The University College Dublin Calendars for the sessions 1911-12, 1912-13 and 1913-14 confirm that she was in receipt of a King's County scholarship in each of her three years of B. Comm. study. These county scholarships were open to students of either sex and were awarded in the order of merit in which the candidates stood in the results of the special examination for county scholarships, held in September by University College Dublin. In addition, to qualify for a scholarship, candidates must have provided testimonials as to their character from a clergyman and their principal school teacher. A final condition was that scholars must reside in a university hostel. There was provision that, in the case of a scholar showing special capacity in Commerce or Science, the scholarship could be extended to a fourth year, indicating that these subjects were more favoured than scholarships in Arts, Architecture, Engineering or, indeed, Law, for which no scholarship was available (Return of Scholarships, 1913).

\section{THE UNIVERSITY YEARS}

An entry in the National University of Ireland Calendar (1912, pp. 407-408) reports that Lilian M. Deignan was among a number of (listed) students who, having passed the Senior Grade Examination of the Intermediate Education Board for Ireland, had been registered as matriculated students of the National University of Ireland. Thus, Lilian Deignan (and Thomas Fitzpatrick) commenced their studies in the Commerce faculty in autumn 1911; we have no record of other students enrolling at that time. There were 765 students at University College Dublin for the academic year (1911-12), of which 137 (18 per cent) were women, and overall student numbers for 1912-13 and 1913-14 (with the percentage of women in parenthesis) were 880 (19 per cent) and 871 (21 per cent) respectively (Report of the President, 1935-36, p. 24).

While the number of registered Commerce students at University College Dublin was, initially, very small, they should be viewed in the context of a growing awareness of and participation in commercial (and technical) education in Ireland at the beginning of the twentieth century. One of the first major developments in this area was the passing of the Local Government (Ireland) Act 1898, which provided for the creation of local councils throughout Ireland; the Act empowered these newly created county and borough councils to levy a rate to provide money for technical education (Coolahan, 1981, p. 87). The following year, the Agriculture and Technical Instruction (Ireland) Act 1899 was enacted, at the height of the Victorian boom in legislation. This Act established a new Department of Agriculture and Technical Instruction, which, in turn, set up technical schools in which classes were designed 
to be mainly related to the needs of the local community, but with a vocational or technical focus. The Act also made available, on top of the local rate, an annual sum of $£ 55,000$ for the provision of such education.

Thus, for example, the Rathmines School of Commerce was founded in 1901 and was devoted solely to commerce and commercial instruction (Clarke et al., 2010). In 1906, the Waterford Technical Institute was formed, which also included commercial education in its curriculum (Hearne, 2006). In 1906, the Belfast Municipal Technical Institute opened to students, and a formal opening ceremony was held in 1907 (McCoy, 2009). Thereafter, in 1908, the Cork Municipal School of Commerce was formed, along similar lines as Rathmines, largely at the behest of the local Chamber of Commerce (Cork Incorporated Chamber of Commerce and Shipping, 1918). Moreover, in 1910 the Irish Society of Arts and Commerce was founded, holding examinations in a variety of commercial subjects with examination centres in many provincial locations. By 1920 it had 1,138 candidates for its examinations (Freeman's Journal, 13 November 1920, p. 5). ${ }^{5}$ One of the Society's presidents, F.C. Wallis-Healy, argued that commercial examinations had 'been largely in the hands of English examining bodies, but ... the time had arrived when these matters could be dealt with by an Irish examining body' (Freeman's Journal, 5 December 1923, p. 3). Several secondary schools reported the fact that its students were successful in the Society's examinations. In addition, it is interesting to note that in the first year of its existence, the Society had two presidential positions, one being filled by Professor Windle, who was President of University College Cork, and the second position being filled by Professor Tom Kettle, Professor of National Economics at University College Dublin (Irish Times, 24 January 1911, p. 3). All the above institutions reported large and increasing numbers of (evening) students each year, and their graduation ceremonies, together with names of successful candidates, were well reported in the national and local press. Such publicity provides evidence of expanding business activities and a growing middle class in Irish society around the turn of the century, which generated the need for more commercial education. In such an environment, one can validly argue that knowledge of commercial matters would be a considerable source of advantage in gaining employment and this may have been particularly the case for females, who may have had to compete with male candidates in employment applications.

We can only speculate as to why Lilian Deignan selected the infant Commerce degree in contrast with, say, Arts. A probable reason is provided by Ó hÓgartaigh (2011), who points out that many female school pupils around that time concentrated on modern languages to the neglect of Latin. For example, the Report of the Intermediate Education Board for 1909 (Intermediate Education Board, 1910) states that 3,656 girls presented themselves for examination in 1909, of whom only 746 (20 per cent) sat Latin. In contrast, 7,676 boys presented themselves, of whom 4,297 (56 per cent) sat Latin. Under the regulations at that time (National University of Ireland Calendar, 1912, pp. 175, 176), the subjects of Latin or Greek were required for matriculation. However, Latin (or Greek) was not required for 'students entering for degrees in Science and Commerce'. It is this language restriction which may have accounted for Lilian Deignan studying Commerce, and which may also explain the relatively high proportion of female students in Commerce faculties. 
Clarke

At that time, the Faculty of Commerce at University College Dublin consisted of three Commerce-orientated professors: Charles Oldham (dean and Professor of Commerce), Tom Kettle (Professor of National Economics) and Reverend Thomas Finlay SJ (Professor of Political Economy). In addition, there were two lecturers. Donal O'Connor was the lecturer in Accountancy and was a chartered accountant as well as being the 51st articled clerk of the Institute of Charted Accounts in Ireland (Chartered Accountants Ireland, 2013). He was a member of the National Council of the Sinn Féin movement, auditor of Dáil Eireann from 1919 to 1922, and was also a personal friend of Arthur Griffith, Patrick Pearse and Michael Collins (Irish Independent, 18 March 1935). Francis Leet was the lecturer in Banking and Finance. He was a barrister who played a large part in assisting in the formation of the Institute of Bankers, for which he was the first secretary (White, 1998). In addition, membership of the Faculty of Commerce comprised various professors and lecturers in law, history and languages based in other faculties in the college (UCD Calendar, 1918-19). It is interesting to note that the general regulations for students of the university were rather severe in comparison to modern times. For example, students were required to 'show due obedience to the President, [and] Professors [and were] expected to attend all the lectures given in each course for which [they were] entered'. The fees were $£ 10$ for the first and second years in Commerce and $£ 8.10 .0$ for the third and final year (UCD Calendar, 1911-12).

Unfortunately, the Faculty of Commerce minute book for the years coinciding with Miss Deignan's period of study in the faculty has been mislaid. ${ }^{6}$ However, the university reported (Report of the President, 1911-12, p. 52) that Lilian Deignan passed with honours her first university exam in Commerce, obtaining first class honours in Commerce and Italian and second class honours in English. Subsequently, the Governing Body of University College Dublin awarded Lilian Deignan an Exhibition of $£ 10$ on the basis of her first year results (Irish Independent, 3 August 1912). Indeed, she was the sole recipient of such an award from the Faculty of Commerce and, by definition, the first recipient of such an award from the newly established Faculty of Commerce. However, it should be noted that only two students entered for and passed the First Commerce examination in Summer 1912, which was the lowest number of students recorded in any faculty, as highlighted in Table 1.

TABLE I: FIRST-YEAR EXAMINATION IN UNIVERSITY COLLEGE DUBLIN SUMMER 1912

\begin{tabular}{lc}
\hline \multicolumn{1}{c}{ Course } & Number of Students \\
\hline Arts & 100 \\
Commerce & 2 \\
Engineering & 14 \\
Law & 7 \\
Medicine & 23 \\
Science & 19 \\
\hline
\end{tabular}

Source: Figures extracted from the Report of the President, 191 I-12, p. 12 
The regulations at that time (UCD Calendar, 1911-12) required that candidates for the First Commerce examination were required to present themselves in five of the subjects listed in Table 2.

TABLE 2: FIVE SUBJECTS TO BE CHOSEN FROMTHE FOLLOWING LIST FOR FIRST COMMERCE

I. Mathematics

2. Commerce I

3. English or Modern History

4. One of the following: Modern Irish, French, German, Italian, Spanish or Welsh

5A. A modern continental language (not already selected in Option 4 above), or

5B. Experimental Physics, or

5C. Chemistry

Source: UCD Calendar (|9|3-|4, p. 397), but variation can be noted from year to year

The reader will notice the absence of what would now be described as important commercial disciplines in the above first year regulations, such as Accounting, Banking and Finance, Economics or Business Administration. Indeed, the above choices, with the exception of Commerce I, were to be taken as part of the normal courses offered, as appropriate, in the Faculties of Arts or Science (UCD Calendar, 1911-12). In addition, Commerce I was scheduled at the unsociable time of 5-6 p.m. each Monday, Wednesday and Friday, presumably to facilitate non-university students with employment commitments. However, it must be remembered that university education in Commerce in both Ireland and England was relatively novel. Indeed, the Dublin Commissioners invited representations and received evidence from the newly created universities in England (Birmingham, Leeds, Manchester and London) regarding curriculum issues. Thus, it should not be a surprise that the three-year Commerce curriculum in University College Dublin had many similarities with that of, for example, the University of Manchester, which included Political Economy, Geography, Modern History, one modern language and a few specialist subjects such as Accounting, Commercial Law and Banking. The Dublin Commission also received evidence on staffing and the Vice-Chancellor of Manchester University indicated that the specialist commercial subjects were taught by 'two or three practical local men, who lecture on the subject who are not professors, and who only come occasionally' (Dublin Commission, 1909, pp. 27-28).

The UCD regulations required that candidates for the Second and Third Commerce examinations present themselves in the seven subjects laid out in Table 3 and lectures on Accountancy, Commerce, Banking and Finance were all scheduled in the evening. However, the University College Dublin Calendar (1913-14, p. 474) contained an interesting 'warning' regarding the Accountancy courses, which extended over a period of two years. Students were informed that they must have acquired a competent knowledge of bookkeeping before entering the course in accountancy, ${ }^{7}$ and that this knowledge was to be acquired either before matriculation, or, alternatively, during their first university year. Students were invited to 
Clarke

'consult the lecturer in Accountancy, who will conduct a class in elementary bookkeeping suitable for their requirements, on days which he will arrange.'

TABLE 3: SUBJECTS IN SECOND- AND THIRD-YEAR COURSE FOR B. COMM. DEGREE AT UCD

\begin{tabular}{ll}
\hline \multicolumn{1}{c}{ Second-Year Course } & \multicolumn{1}{c}{ Third-Year Course } \\
\hline Accountancy I & Accountancy II \\
Commerce II & Commerce III \\
Commercial Law (Course A) & Commercial Law (Courses B and C) \\
Political Economy & National Economics \\
& Banking and Finance \\
Two from: French, German, Italian, Spanish, Experimental Physics, Chemistry \\
\hline
\end{tabular}

Source: UCD Calendar, 1913-14

${ }^{a}$ Accountancy I included preparation of year-end accounts from the trial balance, including adjusting entries for depreciation, bad debts, accruals and prepayments; accounts for non-trading concerns and institutions; valuation of stocks and sinking funds; valuation of goodwill; capital accounts including share issue; and the distinction between a receipts and disbursement account and an income and expenditure account (UCD, I9| I-12).

${ }^{b}$ Accountancy II included the study of special accounts such as partnership accounts, accounts for executors, administrators and bankrupts; branch accounts; hire purchase; costing for contracts; and internal check. It should be noted that some variation occurred from year to year.

The UCD Archives retrieved the examination record of Lilian Deignan, shown in Table 4, which indicate the following marks in her subjects, with the gross marks obtained being reported in relation to the marks available for that subject. The equivalent percentage is also indicated for convenience.

TABLE 4: LILIAN DEIGNAN'S REPORTED MARKS IN B. COMM. DEGREE EXAMINATION (19|4)

\begin{tabular}{lcc}
\hline \multicolumn{1}{c}{ Subject } & Gross Mark Obtained/Total Available & Equivalent \% \\
\hline Political Economy & $450 / I, 000$ & $45 \%$ \\
National Economics & $320 / I, 000$ & $32 \%$ \\
Commercial Law & $840 / 1,000$ & $84 \%$ \\
Commerce & $1,653 / 2,400$ & $69 \%$ \\
Banking and Finance & $470 / 1,000$ & $47 \%$ \\
Accountancy & $1,000 / 1,500$ & $67 \%$ \\
French & $500 / 1,000$ & $50 \%$ \\
Italian & $550 / 1,000$ & $55 \%$ \\
Grand total and average & $5,783 / 9,900$ & $58 \%$ \\
\hline
\end{tabular}

Source: UCD Archives, 2013

It is not entirely clear from the exam regulations contained in the Calendar of University College Dublin how the above total available marks were obtained or applied and why separate marks were returned for both Political Economy and National Economics. Nevertheless, an average mark of 58 per cent was obtained by 
Lilian Deignan. It is possible that her relatively poor mark in National Economics deprived her of obtaining an Honours degree award. Indeed, under current exam regulations in the university, a candidate returning such individual and aggregate marks could expect to receive an honours award. Certainly, exam candidates now have the right to view their exam script and appeal the mark awarded, a facility not available to Lilian Deignan at that time.

However, the Irish Times reported that Lilian Deignan obtained her B. Comm. degree in autumn 1914, at a pass grade - a considerable achievement in itself. She was one of two graduates, the other being Thomas Fitzpatrick (Irish Times, 17 October 1914). Indeed, the UCD exam broadsheets only report two candidates sitting the B. Comm. degree at that time - Lilian Deignan and Thomas Fitzpatrick (National University of Ireland, 2013). Because degrees are presented at graduation in alphabetical order, Lilian Deignan would have been the first to receive her parchment at graduation and therefore became, in October 1914, the first B. Comm. graduate of University College Dublin. Thus, Lilian Deignan has the distinction of being the first person to be conferred with a B. Comm. degree from University College Dublin and she was also the first female to be conferred with a B. Comm. degree by an Irish university. ${ }^{8}$ The Report of the President (1913-14, p. 17) confirms that the first B. Comm. degrees in University College Dublin were awarded in 1913-14 and the Faculty of Commerce had the lowest number of graduates (2), compared with 93 in Arts, 40 in Medicine, 16 in Science, 7 in Engineering, and 8 in Law. It should be noted that, in modern times, many B. Comm. graduates now enter the accountancy profession. However, the career route of chartered accountancy was not available to Lilian Deignan since women were not permitted to obtain membership of the Institute of Charted Accountants in Ireland. However, at its AGM in 1919, the Institute of Chartered Accountants in Ireland was the first of the chartered bodies to permit the admittance of women members. Robinson (1964) reports that Miss Eileen Woodworth became the first lady member of the Irish Institute, being admitted to 'articles' in 1920 and subsequently qualifying in $1925 .{ }^{9}$

In 1915 Lilian Deignan was one of the 28 students who graduated with the Higher Diploma in Education from University College Dublin, but she was the only B. Comm. graduate in that group, all the others having BA degrees (Irish Times, 25 June 1915). The curriculum for the Higher Diploma in Education at that time involved five hours each week in the Theory of Education and five hours per week in Demonstration of Teaching Method; and each student was required to teach, in a suitable school and under the supervision of the Professor of Education, for at least one hundred hours during the year (UCD Calendar, 1914-15). The combination of a B. Comm. degree and a Higher Diploma in Education could have opened up a career in secondary school teaching for Lilian Deignan; however, this avenue was not pursued by her for reasons unknown.

\section{LIFE AFTER UNIVERSITY}

Subsequent to graduating from University College Dublin, Lilian Deignan worked in the Bank of Ireland; it appears she was stationed at the Shipquay Street branch in 
Derry and served there during World War I (Buckley, 2013). Subsequently, Lilian Deignan joined the civil service and there is an entry in the London Gazette (5 August 1921), dated 14 July 1921, stating that Lilian Mary Deignan was assigned, after open competition, to the clerical class (women) in the Inland Revenue Department. This was a rather unusual time to be working for Inland Revenue since in May 1921, during the Irish War of Independence, members of the Irish Republican Army set fire to the (Dublin) Custom House, which included the Inland Revenue Department. The raid was intended, by the destruction of official papers including income tax records and returns, to cripple the work of public departments operating from the Custom House building. ${ }^{10}$ However, the Inland Revenue, together with a number of other organs of state, soon began functioning from Dublin Castle (Reamonn, 1981). These relocated employees would have most probably included Lilian Deignan. A few months later, after the War of Independence, Lilian Deignan was transferred to the service of the Irish Free State. It is interesting to note that, under Article 79 of the 1922 Constitution, the transfer of a number of public services, including the Inland Revenue, was deferred (Constitution of the Irish Free State, 1922). By agreement with the British government, these services were administered on an agency basis so that it was not until 6 April 1923 that the Irish Free State became a separate, independent fiscal and political entity (Revenue Commissioners, 1924). This explains why Lilian Deignan's record, as a 'Clerical Officer, Female' with the Revenue Commissioners dates from 15 July 1923. It terminates on 24 August 1930 (Revenue Commissioners, 2013). The termination was due to her marriage, in September 1930, to George R. Buckley. The couple resided at Maxwell Road, Rathgar (Irish Independent, 14 December 1970). George Buckley, a World War I veteran, was an employee of the Civil Works Department at the ESB, having earlier worked in the mid-1920s on the important Shannon Hydroelectric Scheme, which heralded the electrification of Ireland. He subsequently worked on land acquisition for the Poulaphouca Reservoir Scheme in the late 1930s and later the Erne and Lee schemes (Buckley, 2013). However, Lilian Buckley's retirement from the civil service was then necessary since Statutory Instrument 26/04/1924, under section 9 of the Civil Service Regulation Act 1924, provided, inter alia, that female civil servants holding established posts would be required on marriage to resign from the civil service. ${ }^{11}$ It was a time when relations between Ireland and Great Britain became increasingly strained by a prolonged dispute over land annuities; this 'Economic War' lasted six years, by which time trade between the two countries had significantly declined, with a resultant lack of job opportunities (McSharry and White, 2000). It is likely that the lack of job opportunities at that time, coupled with the culture of married women not working outside the home, resulted in Lilian Buckley adopting the role of full-time mother and homemaker.

However, during her married life, Lilian Buckley maintained connections with the community, school friends and members of the St Louis order (Buckley, 2013). For example, she acted as honorary treasurer of Clann Lughaigh - literally translated as the 'Family of Louis' - which included schools at Balla, Carrickmacross, Kiltimagh, Monaghan town and Rathmines; a group photograph of the committee which includes Lilian Buckley in May 1950 was published in the Irish Press (13 May 1950, p. 3). She also served as an officer of the National University Women Graduates' 
Association (Irish Press, 14 July 1956, p. 5). Furthermore, 'Lilian Buckley' is listed as a member of the committee that organised the first juvenile dance under the auspices of the Irish Red Cross Society, which was held in the Gresham Hotel (Irish Independent, 7 January 1946). The Irish Independent (14 December 1970) further reported that Mrs Buckley was a member of the viewing panel of the National Film Institute. The National Film Institute was registered as a non-profit-making organisation in 1945, two years after its establishment, with its original sponsors including the Roman Catholic Archbishop of Dublin, the Most Rev. Dr John Charles McQuaid. The Institute received an annual grant-in-aid from the Irish government which was used to acquire a library of films, including films in Irish, as well as the addition of Irish soundtracks to suitable films and the production of filmstrips in consultation with the Department of Education. The Institute also maintained three mobile units on constant tour of Irish schools during term time showing health films under the control of the Department of Education (Irish Times, 8 April 1959).Within a decade, the Institute reported at its annual meeting that a total of 1,501 films had been acquired, with 102 films being added to the library during the most recent year (Irish Times, 18 February 1956). It is assumed here that Lilian Buckley would have been involved around that time in viewing possible acquisitions for the Institute.

Lilian Buckley (née Deignan) died on 12 December 1970 at St Luke's Hospital, Dublin, aged 77 (Irish Independent, 14 December 1970). She is buried, with her husband George, in Cruagh Cemetery, Rathfarnham (Findagrave, n.d.). She was survived by her son, John, her sister Sister Imelda (Swinford), and her brothers Thomas (Bray) and Michael Joseph (Nenagh). The Deignan family, as reported in both the 1901 and 1911 Census of Ireland, were a Roman Catholic family, with three of the eight children serving in religious orders. Lilian Deignan's eldest brother, John Vincent, entered the Jesuit order in Tullabeg in 1911 after his education in Mungret College in Limerick. The following year he joined the American Province and was ordained in 1924. He served, initially as Professor of Chemistry and subsequently as dean of the Faculty of Science, at Springhill College, Mobile, Alabama, a faculty which he established in the 1920s (Irish Independent, 22 June 1966, p. 2). Lilian's younger brother Francis, also educated at Mungret College, was ordained at the Vincentian All Hallows College in 1926 for the diocese of Natchez, Mississippi. He was appointed pastor of this parish in 1944 and was responsible for a significant building programme (Irish Independent, 22 June 1966, p. 2). Lilian's younger sister Margaret was received into the Convent of Mercy, Swinford and her name in religion was Sister Imelda (Nenagh Guardian, 9 February 1929, p. 7).

Lilian Buckley's (née Deignan) familial association with University College Dublin continued after her graduation. Her son, John Francis, was born on 7 October 1931 and, after attending Synge Street secondary school, would graduate from University College Dublin with a BA in 1954 and, in the following year, with an LL.B. (First Honours). During his university years he was prominent in the Literary and Historical Society where, for example, he served as correspondence secretary for 1952-1953 (Irish Times, 3 June 1952). Around that time, he was also a member of the first Irish debating team, representing University College Dublin, which participated in the Observer Mace University debating competition (Buckley, 2013). John Francis Buckley subsequently qualified as a solicitor in 1956. Thereafter he 
Clarke

was a member of the Council of the Law Society Committee, including acting as chairman of its Education Committee and as junior vice-president. He was also president of the Dublin Solicitors' Bar Association. He became a law reform commissioner (1987-1996) and was one of the first solicitors to serve as a circuit court judge (Buckley, 2013).

\section{CONCLUSION}

In conclusion, this paper has clarified some details about the life of the late Lilian Deignan. Of course, there are limitations to this research due to the difficulties of getting access to archival material, or where archival material does not exist. Nevertheless, it is hoped that this paper acknowledges, belatedly, her significant achievement as the first B. Comm. graduate of University College Dublin - a distinction which can never be taken away from her. Indeed, the only contemporary recognition of her achievement, until now, appeared in the Irish Times (21 November 1914, p. 8) which noted 'It will be a source of pleasure to hear that the distinction of being the first young lady in Ireland to take the degree of Bachelor of Commerce has been won by Miss Lilian M. Deignan, daughter of ex-Head Constable Deignan, Tullamore. Miss Deignan has already given proof of her talents and industry by winning a King's County Scholarship, thus securing entrance to the National University.' In fact, as this paper also reveals, she was the first B. Comm. graduate from University College Dublin. As such, she was an important role model and must have served as a source of inspiration for the early generation of female commerce students. Now, one century on, it is appropriate to remind ourselves of this achievement. Finally, it is also interesting to note that as the total number of B. Comm. graduates from University College Dublin will shortly reach 20,000 students, her grandson, Aidan Robert - recently one of those graduates - is now a chartered accountant (Buckley, 2013).

\section{ACKNOWLEDGEMENTS}

This paper could not have been completed without the considerable assistance of many individuals who undertook various tasks because they wanted to support this pioneering paper. These include John F. Buckley, Attracta Halpin, Seamus Helferty, John Foley, Catriona Mulcahy, Deirdre O'Connor, Margaret Ó hÓgartaigh, Ronan O'Loughlin, Mark Jenkins and Maria Nolan.

\section{NOTES}

Keith Winters has created an important new free resource for family and social history researchers. Based on G. Dagg's (1893) book Devia Hibernia: The Road and Route Guide for Ireland of the Royal Irish Constabulary, it lists all the RIC stations in Ireland, and for each one provides information about the locality together with the 
names and ranks of over 1,500 men of the RIC. The book was compiled and edited by Dagg, who was a district inspector in the RIC, and was published by Hodges Figgis \& Co. in 1893.

2 The counties of birth not represented that evening (Sunday, 2 April 1911) were Carlow, Longford, Waterford and Wicklow. In addition, non-Irish births listed included pupils born in Jamaica, Liverpool and the United States.

${ }^{3}$ The establishment of a (separate) Faculty of Commerce at University College Dublin was no formality even though the Dublin Commissioners received extensive representations from the local community. Evidence from England was also provided and, for example, the Freeman's Journal reported that in four of the youngest universities in England - London, Birmingham, Leeds and Manchester - a chair in Commerce had already been established; and it was argued that Ireland should 'not be slow to follow their lead' (Freeman's Journal, 29 January 1909, p. 7). However, a subsequent report on the faculty stated that 'the establishment of this Faculty was an afterthought, and it was done as an experiment and upon a provisional basis' (National University of Ireland, 1919, p. 7). A Belfast Commission was responsible for deciding on the structure of and appointments to Queen's University Belfast.

4 Two days previously, the Dublin Commission appointed Mr Timothy Smiddy, MA, FCS, as Professor of Economics and Commerce at University College Cork, and a lectureship in accounting was also created (Freeman's Journal, 22 July 1909, p. 6). Professor Smiddy is perhaps better known for his role as economic advisor to the Irish plenipotentiaries for the Anglo-Irish Treaty negotiations from October to December 1921 following the War of Independence, and subsequently as Ireland's first ambassador/overseas minister, serving as minister plenipotentiary and envoy extraordinary to the United States of America for the Irish Free State from 1924 to 1929 (Davis, 1996). The Faculty of Commerce at University College Galway did not exist at that time (Clarke, 2005).

5 The examinations of the Irish Society of Arts and Commerce included subjects such as English, Irish, German, French, Spanish, Esperanto, commercial correspondence and office routine, handwriting, commercial law, theory and practice of commerce, commercial history, geography, economics, geometry and drawing, arithmetic, book-keeping including banking and accountancy, indexing and précis writing, shorthand and typewriting (Freeman's Journal, 24 January 1909, p. 3).

6 A handwritten note in the Faculty minute book, dated 14 June 1927, reads 'The minute book containing the minutes of meetings prior to June 1927 is not available. It was probably in the possession of the late Professor Oldham' who was the dean at that time (Faculty of Commerce, 1927, p. 20).

7 The Bookkeeping subject at Senior Grade of the Intermediate Examination required an elementary knowledge of, for example, the following: auditing, bookkeeping, liquidation of limited liability companies, and accounts of bankrupts, executors and trustees (Intermediate Education (Ireland) 1910).

8 The first B. Comm. student to be conferred by an Irish university was John Florence Burke, who was conferred with a B. Comm. by University College Cork on 25 October 1913 (National University of Ireland Calendar, 1914). He obtained first class honours in Economics and second class honours in Commercial Technique and was awarded a scholarship tenable at the London School of Economics (Freeman's Journal, 11 October 1913). Two graduates, Frederick T. Lloyd Dodd and William Aubrey de Vere Dodd, had graduated in summer 1913 from the Faculty of Commerce in Queen's University Belfast but they were conferred with a B.Sc. degree (Queen's University of Belfast Calendar 1913-14, p. 682).

$9 \quad$ Around that time the Institute of Chartered Accountants in Ireland was a very small body. Robinson (1964) states that when the First World War broke out in 1914, the Irish Institute had 116 members; there was a total of 156 articled clerks, of whom five were admitted during the year, and this compares with an approximate annual intake of about ten students around that time. In addition, articled clerks were required to pay a premium to their principal and serve, in the case of university graduates, a three-year period of training.

10 Lilian Deignan told her son, John, that she was present in the Custom House the day it was burned (Buckley, 2013).

11 The requirement for female civil servants to retire on marriage had been a regulation since 1924 . Subsequently, the Civil Service Regulation Act 1956 and the Civil Service Commissioners Act 1956 placed in statute law the requirement that female civil servants would face mandatory retirement on marriage. This provision was finally repealed by the Civil Service (Employment of Married Women) Act 1973. The legislation was prepared by the Fianna Fáil party when in office; however having lost power in the 1973 general election, the reforming legislation was introduced by the new Fine Gael-Labour government. 
Clarke

\section{REFERENCES}

Academic Council (1911). Minutes of the Academic Council of University College Dublin, 9 October 1911.

Andrews, C.S. (1982). Man of No Property, Dublin: Mercier Press.

Bartlett, T. (2010). Ireland: A History, Cambridge: Cambridge University Press.

Buckley, J. (2013). Conversation between John F. Buckley (son) and the author at University College Dublin, Friday 1 February 2013.

Chartered Accountants Ireland (2013). E-mail confirmation from the Education and Training Department of the Institute, 18 April 2013.

Clarke, P. (2005). The Story of Bernard F. Shields: The First Professor of Accountancy in the UK, Accounting History, Vol. 10, No. 2, pp. 103-123.

Clarke, P., Ó hÓgartaigh, C. and Ó hÓgartaigh, M. (2010). A Distinct Degree in Commerce: Charles Hubert Oldham and the Establishment of University-Level Commerce Education in Ireland. Irish Accounting Review, Vol. 17, No. 1, pp. 1-19.

Constitution of the Irish Free State (1922). An Act to Enact a Constitution for the Irish Free State (Saorstát Éireann) and for Implementing the Treaty between Great Britain and Ireland signed at London on the $6^{\text {th }}$ day of December, 1921, No. 1/1922.

Coolahan, J. (1981). Irish Education: Its History and Structure, Dublin: Institute of Public Administration.

Cork Incorporated Chamber of Commerce and Shipping (1918). Cork Commercial Handbook, Cork: Cork Incorporated Chamber of Commerce and Shipping.

Davis, T. (1996). Diplomacy as Propaganda: The Appointment of T.A. Smiddy as Irish Free State Minister to the United States, Éire-Ireland, Vol. XXXI, Nos. 3-4, pp. 117-129.

Dagg, G. (1893). Devia Hibernia: The Road and Route Guide for Ireland of the Royal Irish Constabulary, Dublin: Hodges Figgis \& Co.

Dublin Commission (1909). Dublin Commission (Irish Universities Act, 1908). Report of Conferences with University Authorities and Representatives of Chambers of Commerce, Institutes of Architecture and Music, and Other Persons, as to Provision for Technological, Commercial, and Other Subjects in the National University of Ireland, Dublin: Stationery Office.

Faculty of Commerce (1910). Minute Book of the Faculty of Commerce, National University of Ireland (held in UCD Archives).

Faculty of Commerce (1927). Minute Book of the Faculty of Commerce, National University of Ireland (held in UCD Archives).

Findagrave (n.d.). Lilian M. Deignan Buckley, Findagrave, available from: <http://www. findagrave.com/cgi-bin/fg.cgi?page=pv\&GRid=72792916>, accessed 9 January 2013.

Flesher, D. and Flesher, T. (2003). Biographical Research in Accounting, in R. Fleischman, V. Radcliffe and P. Shoemaker (eds), Doing Accounting History: Contributions to the Development of Accounting Thought, Boston, MA: Elsevier, pp. 97-120.

Freeman's Journal (as dated). Dublin.

Gaughan, J. (1975 [reprinted 2012]). The Memoirs of Constable Jeremiah Mee, RIC, Cork: Mercier Press.

Hearne, J. (2006). Waterford Central Technical Institute, 1906-2006, Waterford: City of Waterford Vocational Education Committee.

Intermediate Education Board (1910). Report of the Intermediate Education Board for Ireland for the Year 1909, Dublin: His Majesty's Stationery Office.

Intermediate Education (Ireland) (1910). Rules and Schedule Containing the Programme of Examinations for 1911, Dublin: His Majesty's Stationery Office.

Irish Independent (as dated). Dublin.

Irish Press (as dated). Dublin. 
Miss Lilian M. Deignan: The First B. Comm. Graduate from University College Dublin

Irish Times (as dated). Dublin.

Keogh, A. and Keogh, D. (2010). Bertram Windle, the Honan Bequest and the Modernisation of University College Cork, 1904-1919, Cork: Cork University Press.

Lee, J.J. (1990). Ireland 1912-1985, Cambridge: Cambridge University Press.

London Gazette (5 August 1921). Issue 32413, London, p. 6206.

Maxwell, C. (1946). A History of Trinity College Dublin: 1591-1892, Dublin: Trinity College Dublin.

McCarthy, B. (2012). The Civic Guard Mutiny, Cork: Mercier Press.

McCartney, D. (1999). UCD: A National Idea, Dublin: Gill and Macmillan.

McCoy, D. (2009). Creating Belfast, Dublin: Nonsuch Publishing.

McSharry, R. and White, P. (2000). Introduction, in R. McSharry and P. White (eds), The Making of the Celtic Tiger: The Inside Story of Ireland's Boom Economy, Dublin: Mercier Press.

Murphy, J. (1995). The College: A History of Queen's/University College Cork, 1845-1995, Cork: Cork University Press.

National Archives of Ireland (1901). Residents of a house 59.1 in Shinrone (Shinrone, King's Co.), Census of Ireland, available from: <http://www.census.nationalarchives.ie/ pages/1901/King_s_Co_/Shinrone/Shinrone/1468084/>, accessed 29 January 2013

National Archives of Ireland (1911). Residents of a house 13.1 in Duke Square (Birr Urban, King's Co.), Census of Ireland, available from: <http://census.nationalarchives.ie/ pages/1911/King_s_Co_/Birr_Urban/Duke_Square/551373/>, accessed 29 January 2013.

National University of Ireland (1919). Faculty of Commerce: A Report on the Permanent Needs of this Faculty and Its Improved Equipment, Dublin: National University of Ireland.

National University of Ireland (2013). Private telephone conversation with John Kenny, National University of Ireland, who confirmed the relevant entries in the exam broadsheet, 4 February.

National University of Ireland Calendar (1912). Calendar for the Year 1912, Dublin: Alex. Thom \& Co.

National University of Ireland Calendar (1914). Calendar for the Year 1914, Dublin: Alex. Thom \& Co.

Nenagh Guardian (as dated). Nenagh, County Tipperary.

Ó hÓgartaigh, M. (2011). Quiet Revolutionaries: Irish Women in Education, Medicine and Sport, 1861-1964, Dublin: The History Press of Ireland.

Queen's University of Belfast Calendar (1913-14). Calendar for the Session 1913/14, Belfast: Mayne, Boyd \& Son.

Reamonn, S. (1981). History of the Revenue Commissioners, Dublin: Institute of Public Administration.

Report of the President (1910-11). Report of the President of University College Dublin for the Session 1910/11, Dublin: Browne and Nolan.

Report of the President (1911-12). Report of the President of University College Dublin for the Session 1911/12, Dublin: Browne and Nolan.

Report of the President (1913-14). Report of the President of University College Dublin for the Session 1913/14, Dublin: Browne and Nolan.

Report of the President (1935-36). Report of the President of University College Dublin for the Session 1935/36, Dublin: Browne and Nolan.

Return of Scholarships (1913). A Return of Scholarships founded by County Councils and Borough Councils in Ireland under the Irish Universities Act, 1908, Dublin: A. Thom \& Co.

Revenue Commissioners (1924). First Annual Report of the Revenue Commissioners, Dublin: Stationery Office.

Revenue Commissioners (2013). Copy of Employment Record from 15 July 1923 to 24 August 1930. 
Clarke

Robinson, H. (1964). A History of Accountants in Ireland, Dublin: Institute of Chartered Accountants in Ireland.

UCD Archives (2013). E-mail received by the author from the Archives of University College Dublin, 4 February 2013.

UCD Calendar (1911-12). University College Dublin, Calendar for the Session 1911/12, Dublin: Browne and Nolan.

UCD Calendar (1913-14). University College Dublin, Calendar for the Session 1913/14, Dublin: Browne and Nolan.

UCD Calendar (1918-19). University College Dublin, Calendar for the Session 1918/19, Dublin: Browne and Nolan.

White, D. (1998). A Century of Banking: The Life and Times of the Institute of Bankers in Ireland 1989-1998, Dublin: Institute of Bankers.

Winters (1893). Devia Hibernia: The Road and Route Guide for Ireland of the Royal Irish Constabulary, available from: <http://winters-online.net/devia-hibernia/>, accessed 30 January 2013. 